\title{
Stem cell therapy: from evidence-based medicine to emotion-based medicine? The long Italian way for a scientific regulation
}

\author{
Paola Frati ${ }^{1}$, Giacomo Frati $^{2}$, Matteo Gulino ${ }^{1}$, Gianluca Montanari Vergallo ${ }^{1}$, Alessandro Di Luca ${ }^{1}$ and
} Vittorio Fineschi ${ }^{3^{*}}$

\begin{abstract}
On 23 May 2013, the Italian health minister decided to endorse a law regarding controversial stem cell-based therapies in 32 young terminally ill patients, shocking many scientists. According to the international scientific community, these therapies could be dangerous because they were not rigorously tested in humans. This decision was made after many days of media and judiciary pressure. Several lawsuits regarding stem cell-based therapies were brought before the judiciary districts of different Italian regions. We analyzed the Italian legal context regarding the field of pharmaceutical and medical devices, including the European Union trend. A national database - commonly used to manage legal materials for professional or educational purposes or both - was used to find relevant legal cases involving stem cell-based therapies. Stem cell-based therapies endorsed by the new Italian law have been the subject of an important discussion not only in the scientific community but also in various courts. We found several legal actions filed by parents in order to make stem cells available to their young children, who had serious neurodegenerative diseases. The majority of the analyzed legal disputes were settled in favor of the applicants, whereas only two decisions (Courts of Justice of Rome and Florence) rejected the complaint because of the absence of sufficient scientific data regarding stem cell-based therapies. The present Italian situation is influencing the destiny of future young patients and strongly impacting public and institutional opinion. It is a practical example of the complexity of the decision of not providing unapproved scientific stem cell-based therapies when medicine does not have any other alternative therapies.
\end{abstract}

In recent years, an Italian association called the Stamina Foundation promoted a therapy with intravenous or intrathecal injection of mesenchymal stem cells (MSCs) in patients with rare neurological diseases such as spinal muscular atrophy (SMA), Niemann-Pick syndrome, metachromatic leukodystrophy, and Krabbe disease. This therapy is practiced in a major Italian public hospital, where these treatments are paid for by the government. Facing a persistent media campaign claiming that such therapy could not be denied to such small and sick patients despite the lack of scientific evidence of the efficacy of this therapy and ignoring the risks associated with this unproven method, the Italian Government was

\footnotetext{
*Correspondence: vfinesc@tin.it

${ }^{3}$ Department of Forensic Pathology, University of Foggia, Ospedale ' $C$,

D'Avanzo', viale degli Aviatori, 1, Foggia 71100, Italy

Full list of author information is available at the end of the article
}

forced to issue an urgent law. As has been pointed out, 'central to the campaign was the claim that 'compassionate therapy' was being denied to dying children, who had benefited from the treatment, and would worsen or die should the treatment be interrupted' [1]. On 25 March 2013, the Italian health minister decided to endorse a law concerning controversial stem-cell based treatments in 32 young terminally ill patients, appalling the country's scientists. The debate rose in light of the fact that the stem cells involved are not manufactured according to Italian legal safety standards: standards that require good manufacturing practice (GMP) protocols, which means a 'production and testing practice that helps to ensure a quality product' [2]. Thus, to achieve the clinical translation of any pharmaceutical, medical, or biotechnological product, the development of welldefined productive, processing, and culture conditions is 
required by each nation. Many countries have legislated that pharmaceutical and medical device companies must follow GMP procedures and have created their own GMP guidelines that correspond to or are compatible with their legislation. In this way, Italian law, following the European Parliament regulation (2007/1394/EC), established well-defined rules concerning stem cellbased products. Stem cells are defined as 'advanced therapies products' and are equalized to active pharmaceutical products, and a stem cell-based product found to be manufactured in a condition that breaks current GMP guidelines could be declared 'outlaw'. Therefore, full compliance with GMP is a mandatory aspect of stem cell manufacturing. Quite recently, the final conversion of the decree into law 57 (on 20 May 2013) definitively introduced a controlled clinical trial to test the scientific nature of therapy for various diseases for which it is required. The Ministry of Health, making use of the Italian Medicines Agency (AIFA) and the National Transplant Center, promotes the development of a clinical trial, coordinated by the National Institutes of Health, to be completed within 18 months from 1 July 2013, concerning the use of advanced-therapy medicinal products based on MSCs, provided that the above medicines, with regard to the safety of the patient, are prepared in conformance with the guidelines referred to in Article 5 of Regulation (EC) 1394/2007 of the European Parliament and of the Council of 13 November 2007. To ensure the repeatability of therapies in the first period, the arrangements for preparation are made available to the AIFA and the National Institutes of Health. The National Institutes of Health provides highly specialized counseling for patients enrolled. The Higher Institute of Health and the AIFA are organs deputed to the evaluation of the aforementioned experimentation. For this reason, the unexpected decision of the Italian health minister has shocked the scientific community, which considers this stem cell-based treatment dangerous since it has never been rigorously tested. This decision was made after days of media pressure in order to authorize compassionate use of the therapy, and groups of patients in Italy are now pushing to turn it into an 'easily available treatment' to anyone with an incurable illness. The editorial in Nature (18 April 2013, volume 496, 269) entitled 'Smoke and mirrors' focuses on the Italian situation, stating that 'stem-cell therapies are approved by regulatory agencies but others sneak under the radar by exploiting rules allowing compassionate therapy, for example, or by operating in countries such as China or Mexico - and perhaps now Italy - where regulation is less strict' [3].

We agree that patients should be subjected to emerging/experimental treatments but only once safety and efficacy are ensured. Scientific progress in the care of several muscle degenerative diseases has improved the patients' quality of life and strongly increased community expectations in the treatment of certain pathologies. Emerging or experimental protocols (or both) assume a crucial role in all disabling pathologies for which 'standard medicine' does not have an efficacious and successful cure. Despite the open debate in the field, there is increasing evidence supporting the specific applicability of MSCs derived from multiple tissues, to treat serious disabling diseases. Anyway, stem cell-based therapies are not always suitable for all diseases and patients.

In these circumstances, compassionate use programs can be very important because they represent a new hope for patients and their relatives. Recently, the production of stem cells for compassionate treatment (the so-called 'Stamina' project) has been the object of discussion in the scientific community, the courts, and the government. Judges in Italy have authorized "emergency" treatment with stem cell upon request by the families of patients, ignoring the quality requirements imposed by both Italian and European standards. We analyze the facts in order to understand whether it is possible, in Italy, to promote scientific regulation of stem cell therapy.

\section{The facts}

The Stamina method works on the manipulation of stem cells destined for the treatment of various neurodegenerative diseases, including SMA, Niemann-Pick syndrome, metachromatic leukodystrophy, and Krabbe disease. The method was brought to Italy by two Ukrainian biologists and then improved upon; at present, its patent is pending in the US. Since 2008, many patients, especially children, had undergone this method until a criminal investigation underlined (a) inadequate laboratories and missing necessary GMP standards, (b) polluting agents in the products, and (c) incapacity/inability of the treated cells to evolve/transdifferentiate into neuronal cells.

The treatment has been suspended by the government to prevent possible damage since there is no evidence of its beneficial effects. Yet some judges have authorized the continuation of the treatment since some of the patients' families have made a formal request on the basis of the primary health safeguard (granted by the Italian Constitutional Chart). Other judges have denied such a request, stating the need to fulfill the Italian and European requirement of scientific quality in the production of new advanced treatments. This discrepancy has determined a major difference in treatment between patients, explicitly violating the principle of justice and the equality of access to health care. As was recently pointed out, the EU [European Union] Tissues and Cells Directive regulates the quality of all cells used in human therapy 
including human stem cells and requires GMP-based production systems for clinical applications. Additional requirements in terms of quality of procedures and cleanliness of products exist in the case of human stem cells. Aspects including proof of functionality, safety, quality control, storage, and banking need to be addressed before therapy enters the market' [4]. On 23 May 2013, the Italian health minister drew a great deal of criticism by adopting law 57 for the continuation of Stamina method treatments already started in public facilities under the responsibility of the attending physician. This decision is in contrast with European standards and the Italian ministerial decree of 5 December 2006 concerning health care. The European Medicines Agency (EMA) has well-established criteria to define a drug as 'medicine'. The fact that MSCs administered to patients are 'safe' is their essential condition to be defined as 'medicine'. This subjects them to regulation and supervision by the US Food and Drug Administration (FDA), the EMA, and other national agencies such as the AIFA [1].

\section{Definition of compassionate uses}

The term 'compassionate use' describes the use of a treatment that is not yet approved but that was tested as safe and that already shows preliminary evidence of potential efficacy in the absence of a valid therapeutic alternative for the treatment of a single case outside of a formal clinical trial. Compassionate use is a term commonly used in the field of international medical practice to define a way to obtain unapproved medical drugs [5]. Apparently, this could mean unlawful or simply not respectful of the patient's health. Rather, compassionate use is based on community consensus and patient quality of life. Nowadays, medical drugs provided under compassionate use programs are generally considered legal in the majority of Western countries when the requiring patient meets certain conditions. At the international level, a unanimous definition of compassionate use does not exist. The FDA defines unapproved medical drugs as 'investigational drugs'. There are different ways to make unapproved medical drugs available. New unapproved therapy can be provided directly by the sponsoring company for patients who are not eligible for clinical trials (expanded access program) [6,7].

When clinical trials are not available, patients can try to gain access to unapproved medical drugs by making a personal request directly to the hospital (single-patient compassionate use). Regardless of the specific characteristics of the program, compassionate use is a way to provide and facilitate innovative medical options that are still in development. All medical drugs must receive authorization by a supervising board to be marketed within national territory. The AIFA is the national authority that is responsible for drug regulation in Italy. The AIFA holds a crucial role in the care of patients' health. One of the most important activities of the AIFA is to promote good health through medicines and pharmaceutical research/investments. As Italy is a member of the EU, another important mission of the AIFA is to enforce the relationships with the agencies of other member states and, above all, with the EMA. The EMA is the EU authority responsible for evaluating the scientific quality of medicines developed by pharmaceutical industries for the EU market. Generally, all medical drugs approved by the AIFA have been previously authorized by the EMA [8]. For many years, compassionate use has not been a well-regulated area of the law. Medical drugs for compassionate use are defined as medical drugs that are not yet approved by any institutional

Table 1 Italian courts' decisions regarding stem cell-based therapies

\begin{tabular}{|c|c|c|}
\hline Court & Disabling disease & Legal reasoning ruled \\
\hline $\begin{array}{l}\text { Court of Justice, } \\
\text { Venice } 2012\end{array}$ & $\begin{array}{l}\text { Spinal muscular } \\
\text { atrophy (SMA1) }\end{array}$ & $\begin{array}{l}\text { The Tribunal accepted to provide stem cell-based therapies, highlighting that they are not } \\
\text { experimental drugs. The use of them is allowed by the Italian decree, called Turco-Fazio } 2006 .\end{array}$ \\
\hline $\begin{array}{l}\text { Court of Justice, } \\
\text { Matera } 2012\end{array}$ & $\begin{array}{l}\text { Niemann-Pick } \\
\text { syndrome }\end{array}$ & $\begin{array}{l}\text { The Tribunal accepted to provide stem cell-based therapies, operating a counterbalance of opposite } \\
\text { health interests: the right to individual and the right to public health. The absence of efficacious } \\
\text { alternative therapies justify the individual right to health as the prevailing interest to protect. }\end{array}$ \\
\hline $\begin{array}{l}\text { Court of Justice, } \\
\text { Crotone } 2013\end{array}$ & $\begin{array}{l}\text { Niemann-Pick } \\
\text { syndrome }\end{array}$ & $\begin{array}{l}\text { The Tribunal accepted to provide stem cell-based therapies. When the case is urgent and exceptional, } \\
\text { the protection of life and health must be strengthened and addressed toward a compassionate and } \\
\text { personalized point of view. }\end{array}$ \\
\hline $\begin{array}{l}\text { Court of Justice, } \\
\text { Trento } 2012\end{array}$ & $\begin{array}{l}\text { Spinal muscular } \\
\text { atrophy (SMA1) }\end{array}$ & $\begin{array}{l}\text { The Tribunal accepted to provide stem cell-based therapies. To deny the stem cell-based therapy in a } \\
\text { case that does not have alternatives therapies may jeopardize the right to life and the right to health, } \\
\text { determining a possible loss of survival and quality life improvement chances. This might also limit the } \\
\text { technological progress in the field of the medical science. }\end{array}$ \\
\hline $\begin{array}{l}\text { Court of Justice, } \\
\text { Rome } 2012\end{array}$ & $\begin{array}{l}\text { Amyotrophic lateral } \\
\text { sclerosis }\end{array}$ & $\begin{array}{l}\text { The Tribunal did not accept to provide Stamina's stem cell-based therapies. The patient's health is not } \\
\text { sufficiently protected. }\end{array}$ \\
\hline $\begin{array}{l}\text { Court of Justice, } \\
\text { Firenze } 2012\end{array}$ & $\begin{array}{l}\text { Metachromatic } \\
\text { leukodystrophy }\end{array}$ & $\begin{array}{l}\text { The Tribunal did not accept to provide Stamina's stem cell-based therapies. The patient's health is not } \\
\text { sufficiently protected. The absence of scientific data regarding stem cell-based therapies prevent } \\
\text { considering treatment safe and useful. }\end{array}$ \\
\hline
\end{tabular}


board or agency. At the EU level, compassionate use programs fall under regulation $726 / 2004$, which defines ruling community procedures for the authorization and supervision of medicinal products for human and veterinary use and the establishment of an EMA [9]. Article 83 expressly provides a wide discretion for member states in compassionate use. However, the regulation also has the aim of promoting a common approach in defining the conditions of use. The first law that Italy introduced in the field of 'compassionate use' dates back to 2006 ('Turco-Fazio law') [10]. This law authorizes stem cell-based therapies as compassionate use if certain conditions are met. Specifically, the law requires the following conditions: (a) the lack of satisfactory alternative therapies, (b) favorable scientific data published in international journals, (c) informed consent, (d) ethics committee authorization, and (e) gratuity. This law does not provide clear criteria to be used to determine access to innovative drugs/therapies, stating only that therapies must be supported by scientific data published in scientific journals. Recently, an important change occurred in the Italian law pertaining to access to innovative drugs under compassionate use programs. Law 57/2013, introducing systematic legislation concerning quality criteria in the production and use of stem cell lines for medical purposes, implemented the active legislation mentioned above. In particular, the new law stated that all new drugs provided through compassionate use programs must be produced in authorized laboratories. Regarding stem cell-based therapies, the law stated that stem cell line production must be in compliance with specific standards of quality such as GMP standards. By implementing the previous legislation, this new law seems to match with the concept of 'patients' health right'. New drugs and therapies must not cause or bring any damage to patients and should be safe and useful.

\section{Italian case law regarding stem cell-based therapies}

So in this particular social context, several lawsuits regarding stem cell-based therapies have been brought before the judiciary districts of various Italian regions and have been ruled on by different judges. Legal actions against Italian public hospitals have been filed in different courts in order to obtain the opportunity to be treated with MSC-based therapy in public hospitals. Legal actions have been proposed by several sets of parents to get access to stem cells as a treatment for their children, who have neurodegenerative diseases. This possibility had been denied by the AIFA because of the lack of traceability of the product and the lack of GMP quality control. More complaints related to the therapeutic usefulness of the preparation and the absence of side effects have not yet been proven by any trial or publication by any accredited international journal.

The main arguments the courts have considered to allow the infusions are the following: (a) the serious situation seemingly leads to great suffering; (b) at present, there is no alternative treatment or treatment to at least prevent pain to the subjects; (c) the parents of the patients have given consent; (d) it is not the courts' role to determine whether the Stamina method has scientific basis or whether it leads to any therapeutic benefit; (e) the cases examined are not strictly trials but compassionate use, which, according to legislation, requires less scientific regulation; (f) in the cases examined, however, the prescribing physician and the laboratory director take full responsibility; (g) some rare pronunciations have instead stated the lack of therapeutic proof and verifiability of the methodology and the absence of side effects; and (h), finally, some judges have argued that since the cases are growing by the hour, a regulatory intervention would be necessary in order to avoid unequal treatment.

All cases reported here involve the complex interaction between European, national, local, and administrative drug regulation in the treatment of young patients who have serious disabling neurodegenerative diseases for which modern medicine does not have an efficacious cure (Table 1). Although the cases refer to different medical histories (SMA1, amyotrophic lateral sclerosis, Niemann-Pick syndrome, metachromatic leukodystrophy, and so on), they are all characterized by the will to avoid physical or psychic pain (or both) and poor quality of life. The majority of the decisions examined here have been settled in favor of the applicants (patients), allowing stem cell infusions (for example, Court of Justice of Venice, Matera, Crotone, and Trento) [11-14]. Although the majority of the cases examined have been settled in favor of the applicants (patients), we also found some rulings against them. The Court of Justice of Firenze and the Court of Justice of Rome, for example, made two negative decisions. The former referred to a young patient with metachromatic leukodystrophy, and the latter referred to a 54-year-old patient with amyotrophic lateral sclerosis $[15,16]$. Both cases were rejected because, according to the judges, the absence of sufficient scientific data regarding stem cellbased therapies prevented them from considering the treatment safe and useful for the patients. These judgments are important because they provide a different approach to the assessment criteria of innovative and ongoing experimental therapies. The cases described here show how Italy is debating the opportunity to use innovative stem cell therapies. The debate has been recently resolved by law 57/2013, which states that all therapies in progress must be continued and completed. 
The rule is based on the principle that any therapy can be stopped if any damage to patients occurs.

\section{Mapping the way for the correct behavior of doctors regarding stem cell-based therapies}

How did Italian doctors react to the decree establishing specific tasks and wielding influence beyond the relationship with the patient and the administration of therapy? One of the most serious ethical problems facing stem cell science today concerns the large number of gravely ill adult and pediatric patients who search for unproven stem cell treatments.

What worries Italian doctors most is that in Italy not enough is being done in terms of medical research. In fact, the Italian government has not suggested any recommendations made at the international level in this regard [17]. Stem cell research in Italy is regulated only by law 40 (19 February 2004). Under this law, the embryo is recognized as a subject with rights from the moment of fertilization. The law prohibits the use of embryos for any research unless it is specifically aimed toward improving the therapeutic and medical condition of the embryo concerned. Instead, the 2004 law gives widespread support to tissue (adult) stem cell research. This uncomfortable situation is well represented by the petition to suspend the '2008 call for bids for Health Research Involving stem cell projects', which three scientists submitted by means of petition 3751/2009. The Regional Administrative Court of Lazio held that the petitioners were not entitled to challenge the call for bids in question as they were neither institutional recipients' nor 'external institutions linked to the former by specific agreements' $[18,19]$.

The International Society for Stem Cell Research (ISSCR) created an ad hoc task force in February 2008 to establish the 'scientific, clinical, regulatory, ethical and societal issues that must be addressed to ensure that basic stem cell research is responsibly transitioned into appropriate clinical applications' [20]. A year later, the ISSCR published its 'Guidelines for the Clinical Translation of Stem Cells' [21]. The guidelines state: 'In all other circumstances, the ISSCR condemns the administration of unproven uses of stem cells or their direct derivatives to a large series of patients outside of a clinical trial, particularly when patients are charged for such services. Scientists and clinicians should not participate in such activities as a matter of professional ethics. Health-care institutions and research institutions should not participate in such activities'. Furthermore, the ISSCR has created an information leaflet for patients in order to provide detailed information on the subject, available therapies, and proper relationships with their doctors. The patient handbook was created to help patients and their doctors make informed choices when contemplating a stem cell-based intervention either locally or abroad' $[22,23]$.

What do we learn from these informative strategies? The ISSCR strategies were created to reduce the demand for unapproved stem cell therapies, to encourage local governments to crack down on fraudulent stem cell therapy, and to arm patients with information to discourage them from pursuing potentially dangerous stem cell treatments [24]. In a comment on these guidelines, it was pointed out that it is necessary to understand the needs of doctors and support their relationship with patients so they can provide complete information. This then fosters an atmosphere of common purpose, which is crucial to overcome the current uncertainties related to the fact that the effectiveness of these therapies has yet to be scientifically proven [25]. Although the use of stem cell-based therapies under compassionate use programs has a beneficial purpose - to try to match technological advances with the needs of seriously disabled patients - several points of concern may arise involving the physician's mission: (a) the decision-making process, including criteria assessments, in the selection of innovative therapies; (b) the selection of subjects to decide how treatment should be carried out; and (c) informed consent.

\section{The current debate and possible solutions}

The scientific, political, and legal debate that followed the cases above asked: is it ethically acceptable to allow treatment, even if not founded on scientific evidence and proper testing, if it represents a possible treatment for patients who are in situations of great mental and physical suffering? One might administer a treatment, as in this case, based on stem cells, without quality standards in the following circumstances: (a) the patient has a seriously debilitating disease and (b) there are no approved or in-testing-phase treatments for this particular disease. Could the willingness of the patients themselves, or their parents (in the case of minors), bind the physician to provide a therapy not scientifically validated in the case of a particularly serious disease when so-called mainstream medicine fails to provide other options? Should the decision consider not only the quantitative but also the qualitative parameter, regarding remaining life? If suffering is likely to compromise the dignity of the person, is it ethically acceptable to administer treatment outside the ordinary and common rules of clinical trials? On these issues, the Italian debate aims to achieve a fair compromise between the freedom of treatment and the protection of the patient [26].

Italian legislation, section 83 of regulation (EC) 726/ 2004 of the European Parliament and of the Council and the Helsinki Declaration have all weighed in on this matter. Section C35 of the declaration states that when no 
intervention of proven efficacy is available, the physician might adopt an unproven treatment if some conditions are fulfilled: (a) advice from experts must be obtained; (b) consent by patients or by a legally authorized representative is necessary; (c) in the physician's opinion, the new treatment offers at least the hope of saving the patient's life, re-establishing his or her health, or alleviating his or her suffering; (d) where possible, this intervention should be made the object of a research study, designed to evaluate its safety and efficacy; and (e) the new information should be recorded and, where appropriate, be made available to the public [27].

Despite numerous authorizations by the judges, the above-mentioned Italian cases do not appear to reflect the well-established rules laid down to guarantee the reliability of scientific research, because of (a) the impossibility of verifying the Stamina method, (b) the lack of quality requirements in the laboratory, (c) a poor and incomplete demonstration of effectiveness by the parties involved without a third and neutral opinion and, above all, without the support of scientific studies, and (d), finally, the lack of proof of non-toxicity by the product. All of these steps must be verified by the government as a guarantor of public health, not only to meet the public demands for health care but also to offer scientifically validated treatments according to the two general ethical principles of 'non-harmful' and 'beneficial' treatments: (a) not to cause damage or, at least, to investigate by a scientific method the possible occurrence of toxic effects of a product and (b) to provide patient care based on evidence of effectiveness.

The duty to protect health does not oblige the government to accord to the patient any kind of advanced treatment, as his or her unquestionable freedom to take care (or not) of his or her health does not oblige the competent authorities to supply not-yet-validated treatments. Movement of any therapy into a clinical trial requires much more transparency. It also needs a solid theoretical basis for why it should work, backed by scientific evidence, either published or presented confidentially to the appropriate authority (in this case, the AIFA), according to a recent editorial in Nature (11 July 2013, volume 499, 125 entitled 'Trial and error'): 'It is not the right of the individual to decide what treatments should be authorized by the government and put in place in public or private' [28]. It is therefore necessary to apply the general principles of scientific research to ensure that patients who experience the most desperate conditions are not exploited by and subjugated to the interests of science. And compassionate use may not become an easy shortcut to overcome the need for evidence and therapeutic utility in medicine [29].

To be considered ethical, a clinical research study should fulfill the following criteria: (a) enhancement of health or knowledge, (b) scientific validity of the research, (c) fair selection of the subjects involved in the research, (d) favorable risk-benefit ratio, (e) independent review, (f) informed, conscious, and free consent, and (g) respect for the rights of the enrolled subjects, such as privacy and the freedom to withdraw [30].

The first of the stated criteria, in our view, should also be applied to compassionate treatments.

Scientific validity, of course, might not be judged with the same severity applied in ordinary experiments, but at the very least scientific publications demonstrating the scientific possibility of a benefit to the patient should be required.

As for the third requirement, compassionate use may be permitted only in exceptional cases, to prevent it from being used to circumvent the constraints of the experimentation. Section 83 of Regulation (EC) 726/2004 refers to patients with a chronically or seriously debilitating disease or patients whose disease is considered potentially lethal. Italian law (Decree Turco Fazio) might appear more restrictive, since it allows compassionate treatment only in imminent death emergencies or cases of severe disease with rapid progression.

The fourth requirement should be evaluated on the merits of the case concerned. It must assess not only the risk-benefit ratio of compassionate use but also the riskbenefit ratio given by the lack of any alternate treatment. In cases of rapidly progressing diseases, the risk-benefit ratio may be positively evaluated when the scientific literature supports the possibility of reduced risk.

As for independent reviews, this requirement may be fulfilled through the acquisition of expert advice as required by the above-mentioned Declaration of Helsinki, or by the opinion of an ethics committee, as required by Italian law (Decree Turco Fazio).

The requirement for informed consent to the compassionate use has at least two major features. The first is that the level of awareness of the patient is less than in conventional clinical studies, since the risk-benefit ratio is almost completely unknown. The second is the particular vulnerability of patients and their parents in these cases. In fact, faced with the evidence of a seriously debilitating disease on one hand and lack of alternative treatments in the course of experimentation on the other, they might be easily led to hasten decisions, lacking adequate information.

It appears necessary to apply point B26 of the Declaration of Helsinki, which states that the physician should be particularly cautious about consent given by the patient when there is a dependent relationship with the physician or he or she may be consenting under strain. In such situations, the informed consent should be obtained by someone else, who should be suitably qualified and completely independent of this kind of relationship. 
One of the most important duties of physicians involved in the care of young patients is communication and medical counseling. The communication should have a comprehensive approach aimed at providing support not only to patients but also to relatives. Often this kind of patient presents a very dramatic situation. It is very important to avoid false hope and expectations from the treatment. Finally, the patient undergoing compassionate care should be guaranteed rights to privacy, well-being monitoring, and withdrawal from treatment rights without losing the ability to receive any further treatment.

\section{Conclusions}

The cases described here are clearly influencing the destiny of future young patients and strongly impacting the Italian public and institutional opinion. At present, several neurodegenerative diseases in young patients do not have a known treatment in terms of efficacy and safety. The physician's mission should be not only to treat but also to care for patients' quality of life. Medical scientists are developing experimental stem cell-based therapies in human subjects with positive data in terms of improvement in quality of life. In the eyes of patients and their relatives, such therapies represent a new hope [31]. The Italian cases are a practical example of how compassionate use programs may include many ethical and medical concerns involving patients' quality of life and also of the level of complexity of a decision not to provide unapproved stem cell-based therapies when medicine does not offer any other alternative therapies [32]. The crucial point for physicians and the larger community is determining how to use stem cell-based therapies under development for our patients [33].

The rules proposed above seek to promote the freedom of clinical research and on the patients' right to hope, stressing the safeguard of the person not to be damaged or used as a research tool [34]. These values are common to all EU countries, and, therefore, we must work to harmonize the legal systems of all the member states.

The Italian debate is particularly intense since some judges, in open dissimilarity, authorized the administration of stem cell therapy on an urgent basis, favoring the right to health instead of the assurance of the quality of the offered product. Therefore, the recent Italian legislation, $57 / 2013$, has created a serious disparity in access to care by patients. It is suitable, therefore, to underscore once again the criteria that allow access to compassionate treatment in Italy: (a) the lack of an effective alternative treatment, (b) danger to the patient's life or serious damage to his or her health or a case of serious disease in rapid progression, and (c) accountability by the prescribing physician and the director of the laboratory. Yet these requirements are not enough. They must be supplemented by (a) availability of scientific information published in international journals, (b) informed consent by the patient, (c) favorable opinion by the ethics committee, based on consideration of the benefits and risks regarding the case of the individual patient, and (d) compliance with the requirements of pharmaceutical quality. The judgments in favor of the treatment were not made on the basis of scientific evidence but rather on the need to protect the physical and mental health of patients. The extreme suffering that undeniably characterizes the existence of patients subject to the Stamina method pushed several judges to authorize a de facto treatment not meeting the quality certification requirements stated by the law. Although these products are based on stem cells, treated as drugs in Europe and therefore subject to the rules of GMP and in our case also authorization by the AIFA, a breach in this protection system has been made in the name of the right to health, since there are no therapeutic alternatives offered by evidence-based medicine. In this case, can a treatment not based on scientific evidence and normal certification process quality be ethically acceptable? It might be acceptable only in the name of the patient's right as a person focusing on the protection of life, not only in terms of quantity of days but also in terms of quality, as well as the respect of his or her free will. In this case, the administration of such treatment is well outside the basic rules underlying the reliability of scientific research and the guarantee of health protection for the patient. Transparency of research and the need to ensure its quality through the usual traditional paths, in our case, would seem to conflict with the will of the patients involved in the treatment. However, they choose a therapy they consider the only way to both extend life and reduce pain.

The Italian debate is still open. In fact, while many courts are particularly sensitive to the protection of the rights to health and self-determination, legislators tend to be more cautious in order to guarantee the transparency and soundness of scientific research. And where is the patient? Certainly he or she is in the middle of this clash, leaning toward liberty of treatment principles. Those expectations must still be tempered by the public guarantee of reliability of supply of medical care, since the state still must necessarily carry out its own rules, especially in a public health system. The recent legislation authorizing the continuation of therapy only for patients already undergoing treatment for the Stamina method, and forbidding it to everyone else, has only complicated the matter by not considering the rights to health and free access to medical care drugs.

We completely agree that a linking of researchers, research and development teams, producers, and clinicians 
is mandatory to achieve GMP-compliant processes with relevant controls for producing well-defined, safe, and efficient stem cell-based therapies [35]. However, the debate is still in progress within the Italian Parliament and may lead to new changes in the law. The troubled history goes on.

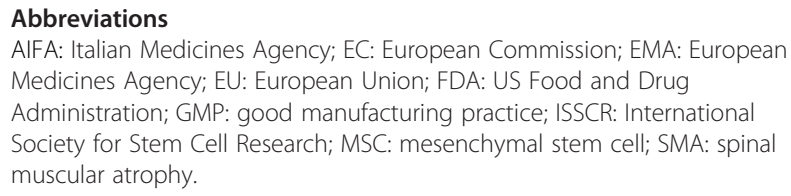

\section{Competing interests}

The authors declare that they have no competing interests.

\section{Authors' contributions}

$M G, G M V$, and ADL assisted with the drafting of the manuscript. PF, GF, and VF conceived of the study, participated in its design and coordination, and helped to draft the manuscript. All authors read and approved the final manuscript.

\section{Author details}

'Department of Anatomical, Histological, Forensic and Orthopaedic Sciences, University of Rome Sapienza, 336 Viale Regina Elena, Rome, Lazio 00185, Italy. ${ }^{2}$ Department of Medico-Surgical Sciences and Biotechnologies, Sapienza University of Rome, Corso della Repubblica 79, Latina 04100, Italy. ${ }^{3}$ Department of Forensic Pathology, University of Foggia, Ospedale ' $C$, D’Avanzo', viale degli Aviatori, 1, Foggia 71100, Italy.

\section{Published: 11 Oct 2013}

\section{References}

1. Bianco P, Barker R, Cattaneo E, Clevers H, Daley GQ, De Luca M, Goldstein L, Lindvall O, Mummery C, Robey PG, Sattler de Sousa e Brito C, Smith A: Regulation of stem cell therapies under attack in Europe: for whom the bell tolls. EMBO J 2013, 32:1489-1495.

2. WHO good manufacturing practices for pharmaceutical products. In WHO Expert Committee on Specifications for Pharmaceutical Preparations. Thirty-seventh report. Geneva, Switzerland: World Health Organization; 2011. Annex 3 (WHO Technical Report Series, No. 911).

3. Smoke and mirrors. Nature 18 April 2013, 496:269.

4. Hovatta O, Stojkovic M, Nogueira M, Varela-Nieto I: European scientific, ethical, and legal issues on human stem cell research and regenerative medicine. Stem Cells 2010, 28:1005-1007.

5. Miracle VA: Compassionate use in research. Dimens Crit Care Nurs 2009, 28:85-88.

6. Hyun I: Allowing innovative stem cell-based therapies outside of clinical trials: ethical and policy challenges. J Law Med Ethics 2010, 38:277-285.

7. Horsburgh CR Jr, Haxaire-Theeuwes M, Lienhardt C, Wingfield C, McNeeley D, Pyne-Mercier L, Keshavjee S, Varaine F: Compassionate use of and expanded access to new drugs for drug-resistant tuberculosis. Int J Tuberc Lung Dis 2013, 17:146-152.

8. Russo P, Mennini FS, Siviero PD, Rasi G: Time to market and patient access to new oncology products in Italy: a multistep pathway from European context to regional health care providers. Ann Oncol 2010, 21:2081-2087.

9. European Parliament and Council. Regulation n. 726/2004 [http://ec. europa.eu/health/files/eudralex/vol-1/reg_2004_726/reg_2004_726_cons_en.pdf].

10. Italian Ministerial Decree Turco-Fazio. December 5, 2006 [http://cfweb. ismett.edu/documenti/allegati_pdf/Legislazione/Decreto_05122006.pdf].

11. Court of Justice of Venezia. Judgment n. 1817. August 31, 2012 [http:// www.personaedanno.it/attachments/article/39888/carrer.pdf].

12. Court of Justice of Matera. September 17, 2012 [http://brescia.corriere.it/ brescia/notizie/cronaca/12_ottobre_9/staminali-daniele-tortorella-spedalicivili-brescia-2112182716694.shtml].

13. Court of Justice of Crotone. January 31, 2013 [http://www. ilfattoquotidiano.it/2013/01/31/cellule-staminali-giudici-autorizzano-terapiaper-bimba-di-5-anni/485413/].
14. Court of Justice of Trento. November 20, 2012 [http://www. personaedanno.it/index.php?option=com_content\&view=article\&id= 41078\&catid $=149 \& \mid$ temid $=396 \&$ mese $=12 \& a n n o=2012]$.

15. Court of Justice of Firenze. December 17, 2012 [http://www.lgiornale.it/ news/interni/giudice-che-vai-cura-che-trovi-caos-sulle-terapie-sentenza895238.html].

16. Court of Justice of Rome. October 12, 2012 [http://salute.aduc.it/staminali/ notizia/].

17. Hyun I, Lindvall O, Ahrlund-Richter L, Cattaneo E, Cavazzana-Calvo M, Cossu G, De Luca M, Fox IJ, Gerstle C, Goldstein RA, Hermerén G, High KA, Kim HO, Lee HP, Levy-Lahad E, Li L, Lo B, Marshak DR, McNab A, Munsie M, Nakauchi H, Rao M, Rooke HM, Valles CS, Srivastava A, Sugarman J, Taylor PL, Veiga A, Wong AL, Zoloth $L$, et al: New ISSCR guidelines underscore major principles for responsible translational stem cell research. Cell Stem Cell 2008, 3:607-610.

18. Regulation of stem cell research in Italy. [http://www.eurostemcell.org/ regulations/regulation-stem-cell-research-italy].

19. Appeal to the Council of State submitted by Elena Cattaneo, Elisabetta Cerbai and Silvia Garagna to overturn order no. 3477/2009 of the Regional Administrative Court of Lazio. [http://www.unipv-lawtech.eu/ lang1/abstract-council-of-state-appeal.html].

20. Task Force on Clinical Translation of Stem Cells. [http://www.isscr.org/ home/publications/ClinTransGuide/clinical-translation-task-force].

21. Guidelines for the Clinical Translation of Stem Cells. Skokie, IL: International Society for Stem Cell Research; December 3, 2008.

22. Patient Handbook on Stem Cell Therapies. Skokie, IL: International Society for Stem Cell Research; December 3, 2008.

23. Daley CG, Hyun I, Lindvall O: Mapping the road to the clinical translation of stem cells. Cell Stem Cell 2008, 2:139-140.

24. Hyun I: Therapeutic hope, spiritual distress, and the problem of stem cell tourism. Cell Stem Cell 2013, 12:505-507.

25. Levine $A D$, Wolf $L E$ : The roles and responsibilities of physicians in patients' decisions about unproven stem cell therapies. J Law Med Ethics 2012, 40:122-134.

26. Bianco P, Biondi A, Bonniolo G, Corbellini G, Cossu G, Cattaneo E, De Luca M, Garattini S, Mantovani A, Pellegrini G, Remuzzi G, Santosuosso A, Vago G: Staminali, lettera aperta al ministro della Sanità. [http://www.lastampa.it/ 2013/03/15/cultura/opinioni/lettere-al-direttore/staminali-lettera-aperta-alministro-della-sanita-26fUzOSvvJLtlulJCWZzYN/pagina.html].

27. WMA - Declaration of Helsinki - Ethical Principles for Medical Research Involving Human Subjects. [http://www.wma.net/en/30publications/ 10policies/b3/].

28. Trial and error. Nature 11 July 2013, 499:125.

29. Rahbari M, Rahbari NN: Compassionate use of medicinal products in Europe: current status and perspectives. Bull World Health Organ 2011, 89:163.

30. Emanuel EJ, Wendler D, Grady C: What makes clinical research ethical? JAMA 2000, 283:2701-2711.

31. Bianco P: Don't market stem-cell products ahead of proof. Nature 2013, 499:255.

32. Goldim JR: Therapeutic uses of investigational drugs: research extension, compassionate use, and expanded access. Rev Panam Salud Publica 2008, 23:198-206.

33. Leonard EW: Right to experimental treatment: FDA new drug approval, constitutional rights, and the public's health. J Law Med Ethics 2009, 37:269-279.

34. Jackson CS, Pepper MS: Opportunities and barriers to establishing a cell therapy programme in South Africa. Stem Cell Res Ther 2013, 4:54.

35. Sensebè $L$, Gadelorge $M$, Fleury-Cappellesso S: Production of mesenchymal stromal/stem cells according to good manufacturing practices: a review. Stem Cell Res Ther 2013, 4:66.

\section{$10.1186 /$ scrt333}

Cite this article as: Frati et al:: Stem cell therapy: from evidence-based medicine to emotion-based medicine? The long Italian way for a scientific regulation. Stem Cell Research \& Therapy 2013, 4:122 